\title{
Cross-Cultural Interactions between Expatriates and Local Managers in the Light of Positive Organizational Behaviour
}

\author{
Sylwia Przytuła \\ Wroclaw University of Economics, \\ Komandorska str. 118/120, 53-345 Wroclaw, Poland
}

\section{Malgorzata Rozkwitalska}

Gdansk School of Banking

Dolna Brama str. 8, 80-821 Gdansk, Poland

\section{Michał Chmielecki}

University of Social Sciences in Lodz, Poland

Gdanska str. 121, 90-519 Lodz, Poland

\section{Lukasz Sułkowski}

Jagiellonian University

Gotębia str. 24, 31-007 Kraków

University of Social Sciences in Łódź

Gdańska str. 121, 90-519 Łódź

\section{Beata A. Basinska}

Gdansk University of Technology

Gabriela Narutowicza str.11/12, 80-233 Gdansk, Poland

cross $^{\text {ref }}$ http://dx.doi.org/10.5755/j01.ss.86.4.9261

\begin{abstract}
The main purpose of this article is to identify the 'individual positive deviance' presented by expatriates and local managers in their mutual cooperation. The theoretical basis for the publication is the discussion of the Positive Organizational Behaviour (POB) essence and the application of this approach in the area of expatriation. Attitudes, behaviour, working style and personality traits of employees of different nationalities and cultures undoubtedly influence the efficient pursuit of business objectives. Empirical knowledge refers to the research concerning mutual positive perception of Polish managers and expats working in subsidiaries of foreign companies established in Poland.

The research in the form of structured interviews was carried out on two groups of managers: 27 expatriate managers working in Poland and 31 Polish managers who cooperate with expatriates during their everyday work.
\end{abstract}

The research findings proved that the individual positives of expatriates from the Polish managers' point of view are: openness to other people and other cultures, cognitive curiosity, sociability and willingness to share knowledge. According to expats, Polish managers are hard-working, dedicated and desired for continuous learning. In interpersonal relationships Polish managers are open, warm and friendly; their approach to many issues is very emotional.

Keywords: cross-cultural (intercultural) interactions, Positive Organizational Behaviour, expatriates.

\section{Introduction}

The development and geographical expansion of international corporations causes that increasingly more often it is necessary to deal with cultural diversity and teams consisting of employees of different nationalities. The cooperation of expatriates with local management 
Social Sciences /

Socialiniai mokslai. 2014. Nr. 4 (86)

results in a number of intercultural interactions ${ }^{1}$ which are both negative and positive.

The practice of managing the expatriation process provides numerous examples of problems and dysfunctional performance in interpersonal relations which result in the failure of a mission (Kraimer and Wayne, 2004; Chen et al., 2010; Takeuchi, 2010). The rate of expatriation failures equals $10-40 \%$ of cases (Scullion and Collings, 2006). The search for the reasons of such adverse phenomena determines the following types of factors: individual ones (e.g. nationality, personality traits, ethnocentrism, racism, stereotypes, lack of knowledge, dilemma of double loyalty) and organisational ones (organisational culture, approach to foreign subsidiaries management). According to Seligman (e.g. Luthans and Youssef, 2007), the absence of psychopathology does not explain optimal functioning, excellence, growth, flourishing and fulfilment. However, positively oriented human traits, states, organizations and behaviours may have a substantial positive impact on performance and other desired outcomes beyond what material resources, classic business models and deficit-oriented approaches can offer.

Yet, it is worth focusing on the positive aspects of diversity in intercultural teams or positive spirals of flourishing (Bernstein, 2003), which facilitate satisfaction, contentment and thus development, enhanced efficiency of activities, and achievement of outstanding results. Such an approach to processes and phenomena occurring in organisations is called 'Positive Organizational Scholarship' - POS (Cameron et al., 2003), 'Positive Organizational Behavior' - POB (Luthans and Youssef, 2007).

The article broadens the perspective of POB in relation to expatriates. The research started within the population of expatriates and local managers at the initial phase of the project and focused on the identification of positive intercultural interactions at the individual, group and organizational level in multicultural teams operating in foreign subsidiaries of multinational corporations.

The detailed research problems dealt with in this article are as follows:

- What are the positive features of expatriates working in Polish subsidiaries?

- What are the positive features of Polish managers in the expatriates' opinion?

- What are the positive outcomes of cross-cultural interactions at individual level?

The main purpose of this article is to identify the 'individual positive deviance' presented by expatriates and local managers in their mutual cooperation. The flourishing personal traits such as optimism, motivation to achievement, open-mindedness, self-effectiveness, cognitive curiosity bring in the positive outcomes of this

\footnotetext{
1 Cross-cultural interactions are a particular form of interpersonal relationships where universal elements (human nature) and specific ones (personality and culture), all in all, collide one another (Rozkwitalska, 2011).
}

S. Przytuła, M. Rozkwitalska, M. Chmielecki, Ł. Sułkowski, B.A. Basinska. Cross-Cultural Interactions between Expatriates and Local Managers in the Light of Positive Organizational Behaviour

relationship like mutual respect, compassion, satisfaction, sense of accomplishment, development, mastery, wellbeing.

This paper begins with a brief literature review concerning relationship between Positive Organizational Psychology (POP), POB, and POS. Then, the relationship between expatriates and local managers is presented. The meaning and importance of some personality traits which determine the success in foreign assignments is also highlighted. In the empirical part of the article, the positive traits of expatriates and local managers are discussed. Conclusions which bring the analysis to a close in this paper come with implications and limitations of the study, and point towards suggestions for future exploration.

\section{Relationships between Positive Organizational Psychology, Positive Organizational Behaviour and Positive Organizational Scholarship - literature review}

Positive organizational psychology, behaviour and scholarship can be located within positive psychological movement (PPM) that came into existence at the turn of the new millennium (Donaldson and Ko, 2010). PPM focuses on 'on strengths, virtues, excellence, thriving, flourishing, resilience, flow, and optimal functioning in general.' (Donaldson and Ko, 2010, p. 177). Although the terms POP, POB and POS have generally been used interchangeably in the scholarly literature, Donaldson and Ko (2010) in their paper posited that these constructs have distinct meanings. Yet, what appears to be common to all of them is a focus on studying positives in the workplace (Figure 1).

POP in its scientific inquiry looks for three types of positives, namely subjective experiences and traits of people in the workplace as well as organizations that bear positive characteristics, while the applicable results of the POP studies are aimed at improving an organizations' functioning (Donaldson and Ko, 2010). The main focus of POB is on individual capacities that constitute psychological capital (so-called PsyCap - see e.g. Luthans and Youssef, 2007), i.e. self-efficacy, optimism, hope and resiliency, and employee characteristics, such as kindness, humor, generosity, which both are to enhance organizational performance (Donaldson and Ko, 2010) and meet the criteria of being measureable, developable and manageable (Luthans, 2002).

POS refers to the study on positives of organizations and their members, including processes, outcomes and attributes. Additionally, POS is concerned with drivers of positives behaviours in the workplace that contribute to exceptional individual and organizational performance. It particularly scrutinizes positive aspects of organizational context (Cameron, 2003).

Despite the differences in the level of analysis between POB and POS, where POB is more individual-oriented while POS concentrates on the organizational level, POB researchers have tended to use a quantitative approach in their studies, whilst in POS studies both quantitative and 


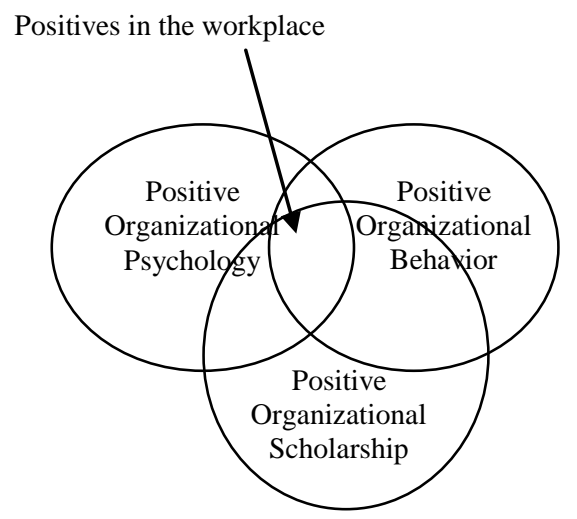

Figure 1. Relationships between positive organizational psychology, behavior and scholarship

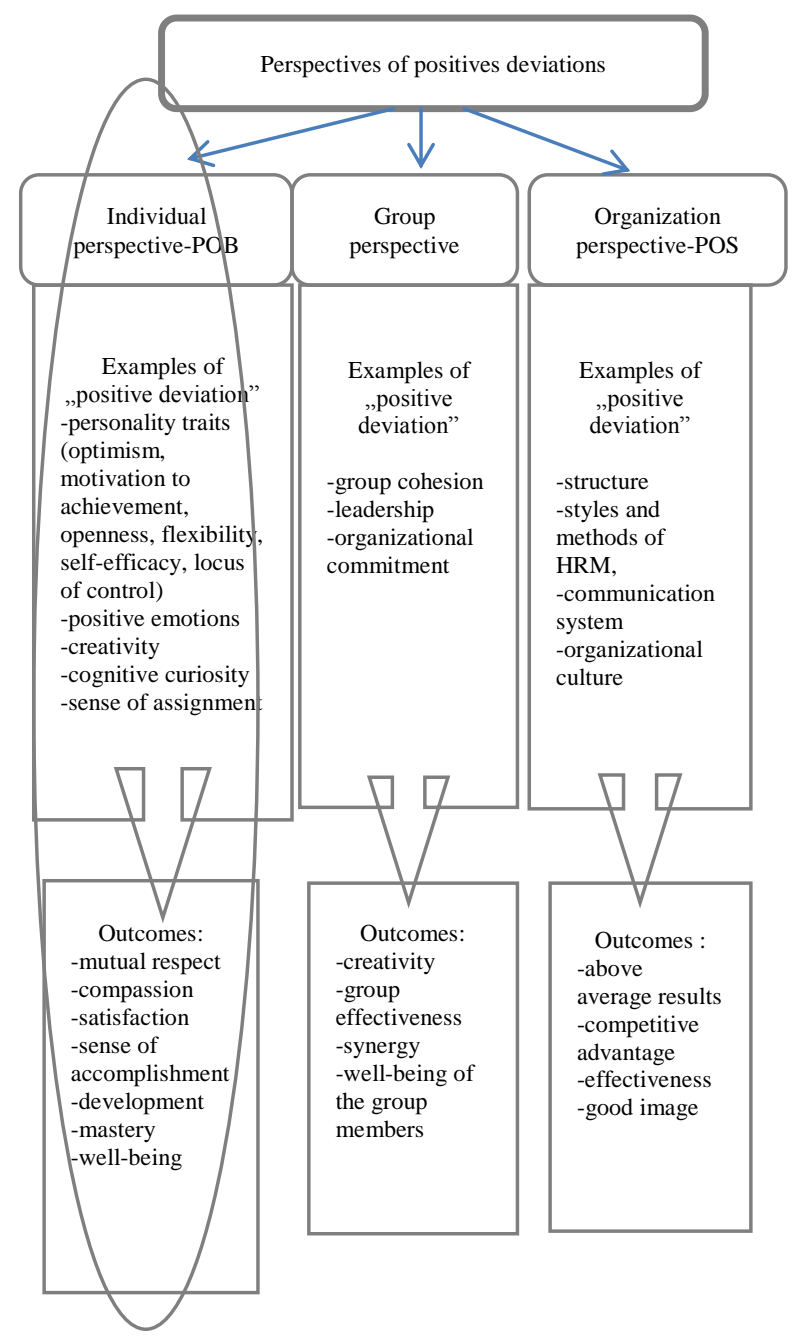

Figure 2. Perspectives and outcomes of positive deviations: individual (POB), group and organizational (POS)

studies are more explorative and explanative by their very nature. In contrast to POS, POB research is rather concerned with 'individual psychological qualities and their impact on performance improvement' (Donaldson and Ko, 2010) to indicate cause-and-effect relationships.
Additionally, with regards to the previous studies (Luthans and Youssef, 2007; Ramlall, 2008), it can be posited that PsyCap that is analyzed with POB lens affects positive outcomes, which are in the core of interest within POS studies. 
Social Sciences /

Socialiniai mokslai. 2014. Nr. 4 (86)

qualitative methods have been applied. Moreover, POS research provide evidence of positives in the workplace and their elevating processes, thus it appears that POS.

POS is aimed at achieving outstanding or unexpected (yet positive) results by an organisation and its employees. Therefore, the analyses are focused on cases of 'positive deviance'. 'Positive deviance' is behaviours of individuals and groups, which enable the arrival at such solutions to problems that are better than those of other people in the organization under the same conditions (Rozkwitalska et al., 2014).

In the context of interpersonal relations between expatriates and local managers, the authors are interested in an individual perspective (Figure 2) and the identification of 'positive deviance' cases in that area which facilitate the achievement of positive results at the level of individuals (mutual respect, development, feeling of fulfilment, expertness, well-being). Thus, the initial conditions for the achievement of positive effects in relation to an individual include first of all such personal traits of managers as optimism, motivation to achievement, open-mindedness, self-effectiveness, cognitive curiosity.

\section{PPM issues in relation to expatriates}

A search of the newest articles published on International Human Resource Management (IHRM) and expatriates within PPM (i.e. POP, POB and POS) of the following databases: Science Direct, Taylor\&Francis Online, EBSCO, Wiley, Emerald, ProQuest, Springer, brought limited results. Only a few works were found and they are summarized in brief below.

Expatriates and host country nationals (HCNs) can function as a part of multicultural teams (MTs). To date, there has been made some effort to examine interactions within MTs with POS lens (see e.g. Stevens et al., 2008; Stahl et al., 2010, Stahl et al., 2010a, Rozkwitalska et al., 2014) that has been concerned with the identification of positive outcomes (such as more creativity, better productivity, learning opportunities, knowledge sharing, effective communication, satisfaction, etc.) as well as their enabling processes (e.g. so-called all-inclusive multiculturalism).

An expatriate in a managerial position can be also seen as a global leader. For example, Youssef and Luthans (2012) imply that the relationships between leaders and followers in a multicultural environment encounter significant strains due to various forms of distance, cultural differences and cultural barriers. Hence, they assert that positive leadership can help to face these challenges effectively by creating invigorating and enabling interactions. Moreover, a positive global leader treats cultural differences as 'unique strengths, capabilities and possibilities to be embraced and leveraged' (Youssef and Luthans, 2012, p. 544), appreciates them and attempts to integrate. PsyCap was depicted as one of the enabling factors in the development of positive global leadership (Story, 2011) along with positive traits and capabilities as well as speaking foreign languages (Youssef and Luthans,
S. Przytuła, M. Rozkwitalska, M. Chmielecki, Ł. Sułkowski, B.A. Basinska. Cross-Cultural Interactions between Expatriates and Local Managers in the Light of Positive Organizational Behaviour

2012). Furthermore, PsyCap was identified as an antecedent of global mindset and a prerequisite of effective global leadership (Storey et al., 2014), while developing such a mindset was perceived to be a major challenge of IHRM.

Ren et al. (2014) in their study on expatriate retention with POS lens demonstrated that proactive tactics such as e.g. relationship building with HCNs positively correlates with expatriate adjustment, being embedded and consequently retention. Thus, those authors suggest that IRHM practices should support, among others, an expatriate's skills concerning fostering social ties.

\section{Expatriates - locals relationships in the literature on expatriation}

The reasons concerning the choice between an expat and a local manager depend on the perspective and planned business of the headquarters and a subsidiary (Scullion and Collings, 2006; Mead, 2009). Thareneou and Harvey identified the advantages and disadvantages of staffing expats and locals in foreign subsidiaries (as cited in Mead, 2009).

Some evidence of positive relationships at work between expatriates and locals along with antecedents and positive outcomes of these interactions can be identified based on the general literature of expatriation which has not been driven by PPM. For instance, Petison and Johri (2008) affirm that an expatriate as a coach should shoulder 'responsibility for creating positive environments and opportunities for local employees to learn', while as a contractor he/she it to help local managers to forge bonds with local suppliers. Thus, as their study proved, an expatriate, who provided support and advice for stakeholders as well as exhibited readiness to work for mutual benefit, created a positive work environment promoting high-quality relationships.

Moreover, Chmielecki (2014) has also pointed out the significant role of coaching in relation to expatriates that results in many intangible benefits at the individual, group and organization level, which improves teamwork, relationships with colleagues, increase job satisfaction and organizational commitment.

Furthermore, building trust between expatriates and locals 'paves the way for efficient cooperation' ( $\mathrm{Li}$ and Kliner, 2001; Petison and Johri, 2008). Additionally, the relevant literature on expatriation highlights the role of acculturation of foreign managers to a local culture as well as HCNs to a foreign culture (so-called local acculturation) in establishing positive relationships between the two parties (Darawong and Igel, 2012).

According to Harzing (2004), the expatriates play specific roles that help to build positive interpersonal relations in multicultural teams. This is the role of a bumblebee passing 'from flower to flower' responsible for the process of socialization between employees of different local units, as well as the role of the spider, involving the building of informal networks of communication and positive interpersonal relationships. The author also 
Social Sciences /

Socialiniai mokslai. 2014. Nr. 4 (86)

stresses the role of a bear, which is a metaphorical picture of the attitudes of domineering expats in the local units and the need for control over the subsidiary management processes.

Dowling et al. (2008) proposed six expatriate roles, some of which relate partly in its content to the concept of POS. The expatriate as an agent of socialization (expatriate assist in the transfer of shared values and beliefs, encourages the adoption of common work practices, aspects of which may comprise of elements of corporate culture. Expatriates function in a role as a network of builders who develop social capital and foster interpersonal linkages that can be used for communication purposes. The role of transferring knowledge and competence ${ }^{2}$ creates an environment of openness and support for cross-fertilization of ideas and implementation of best practices in the foreign subsidiaries.

Interactions between expatriates and local employees are also emphasized in a concept of expatriate adjustment that delineates three facets of it, i.e. general, interactional and work adjustment, whilst interactional ones 'involves comfortably socializing and interacting with host nationals' (Hechanova et al., 2003). Hechanova et al. (2003) founded that, among other factors, frequent interactions of expatriates with locals as well as their selfefficacy had a positive impact on their adjustment, whereas Froese and Peltokorpi (2011) displayed that such an interaction affects an expatriate's job satisfaction in a negative way, if cultural distance between he/she and locals is substantive.

Expatriates-locals relationships were also studied by Chen et al. (2005, p. 429), who disclosed that interdependent goals 'facilitated constructive controversy, which in turn promoted innovation and job commitment'. Those authors also postulated that the expatriate-HCNs interaction may foster the adaptation and application of diverse expertise to a local environment.

Overall, the literature assumes that forming relationships between expatriates and locals is conducive to international assignment success (Bhaskar-Shrinivas et al., 2005) and makes adaptation smoother (Farh et al., 2010; Przytuła, 2014).

\section{Personality traits determining the success in foreign assignments}

In the literature on expatriation the key importance in achieving success during foreign assignments is attributed to individual properties and personality traits such as: motivation to achievement, cultural intelligence, flexibility, open-mindedness, cultural empathy, emotional stability, social initiative, extraversion, cognitive curiosity,

\footnotetext{
${ }^{2}$ According to H. Harris and L. Holden (as cited in Cerdin, 2007), 'expats play a significant role as interpreters and implementers of the HRM practices and business strategy. They contribute to the diffusion of practices and knowledge between headquarters and subsidiaries. The transfer may be from corporate headquarters to its foreign affiliates, as well as from units to headquarter. Expats can therefore be called transferring belts between headquarters and foreign local units'.
}

S. Przytuła, M. Rozkwitalska, M. Chmielecki, Ł. Sułkowski, B.A. Basinska. Cross-Cultural Interactions between Expatriates and Local Managers in the Light of Positive Organizational Behaviour

and optimism (Mamman 1997; Black and Gregersen, 1999; Caligiuri, 2000).

Motivation to achievement in psychology is defined as the need to perform tasks as quickly and well, as it is only possible to achieve or exceed high standards. It is different for different people in its severity, it has an impact on selfesteem and a tendency to strive for success.

Another psychological feature of successful expatriates is cultural intelligence, or the ability to adapt to different cultural realities. Earley and Ang (2003) created a model of cultural intelligence, which consists of three components: cognitive (head), motivation (heart), and behavioural (body). The first component is the ability to gather knowledge on the principles and norms prevailing in a given culture. The second component is the motivation to learn and understand different cultural norms and values and the resulting behaviour. The third element is the ability to quickly assimilate behaviours and attitudes typical of the cultural circle. Inability to imitate the natural and proper understanding of gestures and behaviours typical of the culture testifies to the low development of cultural intelligence in the behavioural sphere.

The issue of flexibility with reference to an employee can be treated as a capability, i.e. an ability to adapt to changes in the environment, cognitive openness, whereas psychologists consider flexibility as a feature which is the permanent and inborn 'equipment' of an individual. It is even mentioned that there is a flexible personality (Przytuła, 2013). Moreover, cultural flexibility is a psychological feature (in 'Big Five', classification according to Costa and McCrae, it is the so-called openness to new experience) which is characterised by openness to cultural diversity, willingness to experiment with other customs and ways of living than one's own

Different researchers have described personality traits which are directly related to expatriates adjustment to foreign cultures. These are open-mindedness, cultural empathy, emotional stability, social initiative, and flexibility (Van Oudenhoven et al., 2003). Openmindedness is defined as an open and unprejudiced attitude towards different groups, culture values and norms. This construct is related to openness to experience. Individuals with a high level of open-mindedness present more positive attitudes towards host citizens. Cultural empathy is a motivational construct which represents the ability to empathize and a better understanding of emotions, thoughts and behaviours of people from a different culture. Individuals with a high level of cultural empathy are more culturally empathic. Then, emotional stability is a tendency to deal with stress, tolerance of ambiguity and social relaxation. Emotional stability is often mentioned as a personality trait that is opposite to neuroticism. In this way, emotional stability reflects the ability to reveal positive feelings in relation to other nations. Furthermore, two

\footnotetext{
3 Big Five personality includes the following traits: extraversion, neuroticism, openness to experience, agreeableness and conscientiousness. They are more related to temperament and other biological correlates (McCrae and Costa, 1997).
} 
Social Sciences /

Socialiniai mokslai. 2014. Nr. 4 (86)

behavioural constructs are mentioned: social initiative and flexibility. Social initiative is the ability to take initiatives, establish and maintain interpersonal relationships and being interpersonally engaged.

To sum up, this approach represents the ability and skills of expatriates to deal with a new culture environment in a better way. These skills and abilities can be changed due to situational facets. Emotional stability and openmindedness are more often related to the Big Five personality traits (openness to experience and neuroticism, respectively). Compared to the personality traits, these abilities may be more useful in understanding the general, interaction and work adjustment to the new culture.

\section{The 'Big Five' set of personality traits}

Many studies on international employees also relates to the diagnosis of personality characteristics of the Big five model. These research studies determined the relationship between personality traits and expatriates' general adjustment and interaction adjustment. Due to the assumptions of this article the key issue seems to be interaction adjustment, and these examples of positive traits that determine positive interpersonal relationships and result in mutual respect, satisfaction, sense of accomplishment, well-being, and self-development.

Bhatti et al. (2014) examined the effects of the Big Five on expatriates adjustment and job performance. Structural equation modelling was applied for data from 201 expatriates in Malaysia. Expatriate general adjustment was positively related to all personality traits, whereas interaction adjustment was directly associated with conscientiousness.

Wang, Freeman and Zhu (2013) noted that agreeableness had a strong relationship with psychological well-being, interaction adjustment and job performance; extraversion was related to performance and adjustment.

Shaffer et al. (2006) examined the direct effect of the Big Five on adjustment among Hong Kong expatriates. The positive effect of extraversion on cultural adjustment and the impact of agreeableness on interaction adjustment were described.

Huang, Chi and Lawler (2005) investigated the relationship between personality traits of eighty-three American expatriates in Taiwan and their adjustment. The result showed that openness to experience, extroversion and prior international experience had the effect of general adjustment. Next, extraversion and agreeableness predicted of interaction adjustment. Finally, openness to experience explained work adjustment.

Studies conducted in a multicultural environment (Huang, Chi, and Lawler 2005; Zajenkowska and Zimmerman, 2014) showed that the Big Five personality traits were associated with the adjustment of expatriates for demands and norms in a host country. Extraversion, openness to experience and agreeableness were better predictors than conscientiousness and neuroticism in a process of adjustment. These three personality traits were related to job performance. Both, general and work
S. Przytuła, M. Rozkwitalska, M. Chmielecki, Ł. Sułkowski, B.A. Basinska. Cross-Cultural Interactions between Expatriates and Local Managers in the Light of Positive Organizational Behaviour

adjustment was better in expatriates with a high level of extraversion and openness to experience. However, agreeableness was the more important predictor for interaction adjustment. Conscientiousness and agreeableness were associated with cross-cultural competence. Finally, the openness to experience was the best predictor for work adjustment among the Big Five personality traits.

The Big Five personality traits have a stronger effect on general adjustment than on work adjustment. This tendency was present in most of the studies. These results correspond to the theoretical background of the Big Five Personality traits' model.

\section{Cross-cultural interactions among expatriates and local managers - practice from Polish subsidiaries}

The survey covered a group of 31 Polish managers who had direct contact with an expatriate in a foreign subsidiary of a corporation in Poland and it was conducted in December 2013/January 2014. The research was based on non-probability sampling, snowball method, used in ethnographic research and cultural anthropology. Those managers came from 17 big companies and they held positions at the middle $(68 \%)$, higher $(23 \%)$ and the highest managerial level $(10 \%)$. The research technique had a form of structured interview questionnaire.

The second group of respondents was 27 expatriate managers working in Poland. They were mainly mid- and top-level managers representing different departments and organisational units of companies. They represented 9 nationalities (American, German, Swedish, Irish, British, French, Spanish, Indian, and Austrian). The study sample was picked by a non-random method, i.e. by a purposive sampling method and by a snowball sampling. They come from companies with a majority of foreign capital. Interviews lasted from about 20-minutes to half an hour. The structure of questionnaire was related to the theoretical background of the research. With regard to the literature review presenting various individual approaches and features of expatriates that make the foreign assignment successful, the research question was focused on diagnosing the positives of expats seen by local managers. On the other hand, the positives of locals from expats' point of view were also presented. In relation to the theoretical model of positive deviations in individual perspective (POB), the research question focused on outcomes of mutual interactions of foreigners and locals.

The detailed research questions were as follows:

1) What are the positive features of expatriates working in Polish subsidiaries?

2) What are the positive features of Polish managers in the expatriates' opinion?

3) What are the positive outcomes of cross-cultural interactions on individual level? 
Social Sciences /

Socialiniai mokslai. 2014. Nr. 4 (86)

\section{Ad.1) Positive features of expatriates working in Polish subsidiaries - the local managers' point of view}

As many as $86 \%$ of Polish managers think that expatriates are necessary in Polish subsidiaries, and therefore they were asked to assess their positives.

When it comes to personality traits, respondents indicated primarily for openness to other people and other cultures, cognitive curiosity, sociability and willingness to share knowledge:

Respondent SA: 'Many expats in our company are people who are open to new challenges, to explore new places, people and processes. These are the citizens of the world in the best sense of that word.'

Respondent SC: 'The foreign managers working in Poland are very different from each other. In an attempt to synthesize the most common characteristics I would point on: the relatively high level of managerial skills at the expense of technical competence, great communication skills, ability to build relationships in a different cultural environment.'

Respondent SD: 'The strength of foreign managers is certainly their openness, the ability to look at the same problems in an innovative way'.

In addition, Polish staff emphasized the expatriates' roles as ambassadors and liaisons between the headquarters and a subsidiary:

Respondent SE: 'They are often depositories of knowhow and are experts in a given area; they also have the ability to transfer their knowledge to others.'

Respondent SF: 'They may transfer knowledge, innovation, as well as proven products and solutions (in the countries they have worked, not widespread in Poland yet).'

Respondent SG: 'They single out with their knowledge of procedures and corporate methods of work'.

Yet, the highest number of strengths and positives of foreign managers referred to expats' knowledge and international experience:

Respondent SM: 'They are very good in foreign languages (English, French, German) and they are very communicative at the same time.'

Respondent SR: 'Expats' horizons of experience are wide - they have usually worked in several countries.'

In spite of numerous examples of positive perception, only a few Polish managers (29\%) had non-professional relations with an expat or their family. The Polish respondents believe that the reason for such a significant gap in non-professional relationships is that the expats often consider their working in Poland as a temporary or transitory condition and therefore they do not want to get emotionally involved and 'invest' in deeper relationships with Polish colleagues. Especially at the beginning of their stay in Poland, expats are bothered by lack of acquaintances and friends. Still, they prefer their own circle of 'assigned persons' to Polish acquaintances. In several companies, the employees of HR departments were responsible for organizing meetings with other expatriates
S. Przytuła, M. Rozkwitalska, M. Chmielecki, Ł. Sułkowski, B.A. Basinska. Cross-Cultural Interactions between Expatriates and Local Managers in the Light of Positive Organizational Behaviour

from the same country of origin working in the same locality. There were occasional meetings during which they could share their first impressions as to their stay in Poland and benefit from advice on dos and don'ts in Poland.

Moreover, pursuant to $71 \%$ of Polish managers, expats in the surveyed companies learn the Polish language, yet with different results. Nevertheless, the Poles appreciate the effort devoted by foreigners in this issue, which facilitates the establishment of good interpersonal relationships in their workgroups.

The knowledge of local language positively influences the perception of foreigners by local employees. It is confirmed by the survey conducted by J. Eisenberg et al. (2009) concerning the leaderships styles among managersexpatriates in Poland. According to it, the expatriates were viewed as sensitive, tolerant, open and friendly, although $65 \%$ of Polish employees think that the knowledge of the Polish language would give the managers from Western Europe greater approval and sympathy from their Polish subordinates.

\section{Ad.2) Positive features of Polish managers in the expatriates' opinion}

Expats emphasize that managerial experience and intercultural is not a strong side of the Polish managers, but they make up for these competency gaps hard work, dedication and desire for continuous learning. In addition, these personality traits and behaviours facilitate mutual cooperation and reduce interpersonal distance:

Spanish manager: 'In the company I work for there are a lot of young managers who lack experience but they make up for it by passion and dedication.'

French manager: 'Regardless of experience. Polish managers are very hard working and dedicated.'

German manager: 'Polish managers work very hard and are very ambitious.'

Swedish manager: 'So far my Polish colleagues belong to the most dynamic and ambitious people I have ever worked with.'

Irish manager: 'My Polish colleagues learn very quickly. They are very intelligent.'

French manager: 'My Polish colleagues are highly motivated and well educated.'

In interpersonal relationships Polish managers are open, warm and friendly; their approach to many issues is very emotional, which is not always well perceived by foreign staff:

American manager: 'Poles are warm and friendly, but doing business is quite slow and sometimes very frustrating.'

Swedish manager: 'They easily get stressed and lose their temper. They take things too personally. Their emotional way of resolving conflict is really stressing for me. It is even hard to think in such a noise and lack of respect of other side's opinions.'

German manager: 'The worst thing is not keeping emotions out of the equation when talking about important 
Social Sciences /

Socialiniai mokslai. 2014. Nr. 4 (86)

things. And you should not discuss things under the influence of emotional arousal, because it allows us to think irrationally, decisions can be made too hastily.'

Foreign managers often emphasize flexibility, creativity and even the ability to improvise, which is appreciated but on the other hand is assessed in moderation and with distance in relation to decision-making processes in mutual cooperation:

British manager: 'Well, they are not always very organized but they are outstanding at improvising. They deal creatively with unexpected situations. And they are very good at it.'

German manager: 'They lack a method that allows them to recognize and manage the various stages of the project. So basically for me it is best to work out a map including chosen strategy which allows avoiding failure which causes financial losses or damages the image. Well planned method together with some couple of modified versions boost my confidence too. But on the Polish side there is a lot of chaos and improvisation, this is not always good.'

German manager: 'There is a lot of improvisation instead of proper preparation. Improvisation is a good thing but is more like a poker game.'

Irish manager: 'Poles have a lot of special skills that they developed in the era of communism. That makes them very good, creative managers.'

On the other hand, submissiveness, lack of confidence in their own competence suppresses the potential personality they have:

German manager: 'Sometimes they don't believe in themselves. This is a really important area for them to improve. If you don't believe in yourself and your skills it is hard to make others to believe in you and put trust in you. And they are smart and intelligent. They must start believing in themselves.'

American manager: 'They are quite submissive. There is a general lack of faith in their own skills and potential. And I do not understand that because they have a lot to offer. They are very smart and creative people.'

\section{Ad.3) The positive outcomes of cross-cultural interactions at individual level}

Positive personality traits and attitudes indicated by expatriates and Polish managers contribute to building positive interpersonal relationships and professional ties. To the results and benefits of positive intercultural cooperation the respondents pointed out: enriching managerial experience, broadening cognitive qualities and personal development:

Respondent SF: 'for me it is mostly a new cultural experience, but also developing the linguistic skills and procedural knowledge, because sending out an employee or employing her/him to our affiliates I need to familiarize with the law procedures and cultural principles which apply in her/his country. I also want to see how different these systems and procedures are in order to be well prepared employing a new expat in our company.'
S. Przytuła, M. Rozkwitalska, M. Chmielecki, Ł. Sułkowski, B.A. Basinska. Cross-Cultural Interactions between Expatriates and Local Managers in the Light of Positive Organizational Behaviour

Respondent SM: 'The benefit is getting to know another culture, rules of cooperation and continuous contact with German and English languages. Through such work I have an ability to know new people-not only expatriates themselves but also their families.'

Respondent SO: 'First of all, mutual cooperation with expats develops my tolerance with respect to the other nationalities. I'm trying to better understand these people, get to know their culture, and I learn to be patient.'

Openness to otherness and experienced cultural diversity is a challenge for the respondents, which gives them a sense of accomplishment and satisfaction:

Respondent SP: 'Working with foreigners, I choose what, in a given culture is the most valuable. For example from the Germans I learned that you have to say specifically, briefly aiming to target. While meeting the Italians first talk down about personal matters and by the way of business. In collaboration with the Indians I learned to ask questions in such way, so that they do not have to admit openly that they do not know something. I feel like a fish in water in such an environment.'

\section{Discussion and conclusion}

As reflected in the introduction of this article, the current status of the theory, research and practice of POB is still emerging. Only through further research can POB be better understood and utilized in business practice. The purpose of this article was to identify the individual positive deviance' presented by expatriates and local managers in their mutual cooperation. The key issue of the research was also to highlight the positive outcomes arising from mutual cooperation.

Thus the individual positives and strengths of the expatriates from the Polish managers' point of view identified in the research were: openness to other people and other cultures, cognitive curiosity, sociability and willingness to share knowledge. Moreover, the local managers appreciated and valued the expats' knowledge and international experience. According to the expats, the Polish managers are hard-working, dedicated and desired for continuous learning. In interpersonal relationships the Polish managers are open, warm and friendly; however their approach to many issues is very emotional. The foreign managers emphasized flexibility, creativity, and even the ability to improvise.

Focusing on positives in individuals gives the possibility of achieving competitive advantage in the many issues of expatriation contributing to general, interaction and work adjustment. The success of foreign assignments depends among others on good, positive adaption to the new work, social and cultural environment. Positive attitude brings in positive results not only on the individual perspective (compassion, satisfaction, sense of accomplishment, development mastery, well-being) but also in group perspective (creativity, group effectiveness, synergy, well-being of the group members) and further, they are the strengths of the organization. 
To the results and benefits of positive intercultural cooperation respondents pointed out: enriching managerial experience, broadening cognitive qualities, personal development, sense of accomplishment and satisfaction.

The research can be referred to the findings by Selmer and Lauring (2013) who investigated how dispositional positive and negative affectivity predict attitudinal and behavioural outcomes in the workplace. The results of the survey including 350 expatriates in Denmark showed that positive affectivity compared to negative affectivity had opposite associations with work adjustment, work performance, work effectiveness and job satisfaction. Positive affectivity seems generally to have stronger relationship with work outcomes than negative affectivity.

Another contribution of this paper is that although the authors focused on the individual level of cross-cultural interactions, the implications of that study may be spread also on group and organizational level. Individuals' positive traits like optimism, openness, cognitive curiosity, sociability can create synergistic effects in multicultural teams, and it is possible that if one person in the team expresses these states and attitudes the entire team can take advantage of it. High-performing teams can create positive social effects throughout an organization.

Even though some indicators of flourishing and some individual strengths of expats and local managers have been identified in the research, much remains unexplored. A more comprehensive research into the Big Five personality traits and its impact on positive cross-cultural interaction in multicultural teams should be done. Furthermore, the measureable results of 'bright side of multicultural team diversity' (Stahl et al., 2010) and their impact on organizational outcomes should be researched.

The value and originality of the research project results from the research subject, which will fill the gap in existing knowledge of cross-cultural interactions in foreign subsidiaries. In relation to the issue of expatriation, it seems to be a key approach, which is searching for advantages and positive aspects arising from mutual cooperation and synergy between foreign and local personnel. The identification of positives in individuals (expats and local employees) gives the possibility of achieving competitive advantage in the scope of human capital in the global market and of achieving outstanding results in all functional areas of an organisation.

Furthermore, the orientation to expatriates' positive features as early as at the stage of their recruitment and selection may contribute to the reduction of risk of expatriation failure arising mainly from expats' personality traits and cultural origin.

\section{Acknowledgement}

The research carried out by the authors is a part of the larger research project entitled: Cross-cultural interactions in foreign subsidiaries of multinational corporations traditional and Positive Organizational Scholarship approach (the research grant no. 2013/09/B/HS4/00498) financed by the Polish National Centre of Science.

\section{References}

1. Bernstein, S.D. (2003). Positive Organizational Scholarship: meet the movement. Journal of Management Inquiry, 12, (3). http://dx.doi.org/10.1177/1056492603256341

2. Bhaskar-Shrinivas, P., Harrison, D.A., Shaffer, M.A., \& Luk, D.M. (2005). Input-based and time-based models of international adjustment: Meta-analytic evidence and theoretical extensions. Academy of Management Journal, 48, 257-281. http://dx.doi.org/10.5465/AMJ.2005.16928400

3. Bhatti, M.A., Battour, M.M., Ismail, A.R., \& Sundram, V.P. (2014). Effects of personality traits (big five) on expatriates adjustment and job performance. Equality, Diversity and Inclusion, 33, (1), 73-96. http://dx.doi.org/10.1108/EDI-01-2013-0001

4. Black, J.S., \& Gregersen, H. (1999). The right way to manage expats. Harvard Business Review, March/April, 52.

5. Caligiuri, P. (2000). The five big personality characteristics as predictors of expatriates' desire to terminate the assignment and supervisor-rated performance. Personnel Psychology, 53, 1, 67. http://dx.doi.org/10.1111/j.1744-6570.2000.tb00194.x

6. Cameron, K.S., Dutton, J.E., \& Quinn, R.E. (2003). Positive Organizational Scholarship - Foundations of a New Discipline. San Francisco: Berrett-Koehler Publishers Inc.

7. Cerdin, J. (2007). The role of expatriates in diffusing HRM practices across the MNC: an agency perspective. In P. Benson, A. Mahajan, R. Alas, R. Oliver (eds.). The $9^{\text {th }}$ International HRM Conference, Conference Proceedings. Tallinn: NMSU College of Business.

8. Chen, G., Kirkman, B. L., Kim, K., Farh, C. I., \& Tangirala, S. (2010).When does cross-cultural motivation enhance expatriate effectiveness? A multilevel investigation of the moderating roles of subsidiary support and cultural distance. Academy of Management Journal, 53, 110. http://dx.doi.org/10.5465/AMJ.2010.54533217

9. Chen, Y.F., Tjosvold, D., \& Su, S.F. (2005). Goal interdependence for working across cultural boundaries: Chinese employees with foreign managers. International Journal of Intercultural Relations, 29, 429-447. http://dx.doi.org/10.1016/j.ijintrel.2005.05.010

10. Chmielecki, M. (2014). Coaching of expatriates' in the process of acculturation. In S. Przytuła (ed.) Expatriates in Poland-a strong or weak link in managing Polish subsidiary? Warsaw: Texterbooks (In Polish).

11. Darawong, Ch., \& Igel, B. (2012). Acculturation of local new product development team members in MNC subsidiaries in Thailand. Asia Pacific Journal of Marketing and Logistics, 24, (3), 351-371. http://dx.doi.org/10.1108/13555851211237867

12. Donaldson, S.I., \& Ko, I. (2010). Positive organizational psychology, behavior, and scholarship: A review of the emerging literature and evidence base. The Journal of Positive Psychology, 5, (3), 177-191. http://dx.doi.org/10.1080/17439761003790930

13. Dowling, P., Festing, M., \& Engle, A. (2008). International Human Resources Management, South-Western Cengage Learning.

14. Earley, C., \& Ang, S., (2003). Cultural Intelligence. Stanford Business Books.

15. Eisenberg, J., Pieczonka, A., \& Eisenring, M. (2009). Evaluating the effectiveness of expatriate managers leadership style in Poland. Paper presented at the VIIIth Annual IACCM Conference, Vienna, Austria.

16. Farh, C., Bartol, K.M., Shapiro, D., \& Shin, J. (2010). Networking abroad: A process model of how expatriates form support ties to facilitate adjustment. Academy of Management Review, 35, 434454. http://dx.doi.org/10.5465/AMR.2010.51142246

17. Froese, F.J., \& Peltokorpi, V. (2011). Cultural distance and expatriate job satisfaction. International Journal of Intercultural Relations, 35 , 49-60. http://dx.doi.org/10.1016/j.ijintrel.2010.10.002

18. Harzing, A. (2004). Composing an international staff. In A.W. Harzing (Ed.) International HRM (p.265). Sage Publications.

19. Hechanova, R., Beehr, T.A., \& Christiansen, N.D. (2003). Antecedents and Consequences of Employees' Adjustment to Overseas Assignment: A Meta-analytic Review. Applied Psychology: an International Review, 52, (2), 213-236. http://dx.doi.org/10.1111/1464-0597.00132 
Social Sciences /

Socialiniai mokslai. 2014. Nr. 4 (86)
S. Przytuła, M. Rozkwitalska, M. Chmielecki, t. Sułkowski, B.A. Basinska. Cross-Cultural Interactions between Expatriates and Local Managers in the Light of Positive Organizational Behaviour

20. Huang, T.-J., Chi, S.-C., \& Lawler, J.J. (2005). The relationship between expatriates' personality traits and their adjustment to international assignments. International Journal of Human Resource Management, 16, (9), 1656-1670. http://dx.doi.org/10.1080/09585190500239325

21. Kraimer, M. L., \& Wayne, S.J. (2004). An examination of perceived organizational support as a multidimensional construct in the context of an expatriate assignment. Journal of Management, (30), 209. http://dx.doi.org/10.1016/j.jm.2003.01.001

22. Li, L., \& Kliner, B.H. (2001). Expatriate-local relationship and organization effectiveness: a study of multinational companies in China. Management Research News, 24, (3/4), 49-56. http://dx.doi.org/10.1108/01409170110782612

23. Luthans, F. (2002). Positive organizational behavior: Developing and managing psychological strengths. Academy of Management Executive, (16), 57-72. http://dx.doi.org/10.5465/AME.2002.6640181

24. Luthans, F., \& Youssef, C. (2007). Emerging Positive Organizational Behavior. Journal of Management, (33), 321-349. http://dx.doi.org/10.1177/0149206307300814

25. Mamman, A. (1997). Expatriates intercultural effectiveness: relevant variables and implications. Asia Pacific Journal of Human Resources, 33, (1), 41.

26. Mead, R., \& Andrews, T.G. (2009). International Management, p.463-465. Wiley.

27. Perlmutter, H., (1969). The Tortuous Evolution of the Multinational Corporation. Columbia Journal of World Business, January-February.

28. Petison, P., \& Johri, L. (2008). Managing local employees: expatriate roles in a subsidiary. Management Decision, 46, (5), 743-760. http://dx.doi.org/10.1108/00251740810873743

29. Przytuła, S. (2013). Flexibility as a Feature and the Ability in the Expatriate' Qualification Profile. Education of Economists and Managers, 1, (27), 51-66.

30. Przytuła, S. (2014). Expatriates in Poland-a strong or weak link in managing Polish subsidiary? Warsaw: Texterbooks (In Polish).

31. Ramlall, S.J. (2008). Enhancing employee performance through positive organizational behavior. Journal of Applied Social Psychology, 38, 1580-1600. http://dx.doi.org/10.1111/j.15591816.2008.00360.x

32. Ren, H., Shaffer, M.A., Harrison, D.A., Fu, C., \& Fodchuk, K.M. (2014). Reactive adjustment or proactive embedding? Multistudy, multiwave evidence for dual pathways to expatriate retention. $\begin{array}{llll}\text { Personnel Psychology, 203-239. } & \text { 67, }\end{array}$ http://dx.doi.org/10.1111/peps.12034

33. Rozkwitalska, M. (2011). Barriers in intercultural management. Foreign subsidiaries' of multinational corporations view point. Warsaw: Wolters Kluwer (In Polish).

34. Rozkwitalska, M., Chmielecki, M., Przytuła, S., \& Sułkowski, Ł. (2014). The Positives of Cross-cultural Interactions. In Multinational Companies and Multicultural Groups. Proceedings of $4^{\text {th }}$ International Conference on Global Business Environment, (pp.202-208). Bangkok: ICGBE.

35. Scullion, H., \& Collings, D. (2006). Global Staffing. NY: Routledge, p.25.

36. Selmer, J., \& Lauring, J. (2013). Dispositional affectivity and work outcomes of expatriates. International Business Review, 22, (3), 568-577. http://dx.doi.org/10.1016/j.ibusrev.2012.08.003

37. Shaffer, M.A., Gregersen, H., Ferzandi, L.A., Harrison, D.A., \& Black, J.S. (2006). You can take it with you: Individual differences and expatriate effectiveness. Journal of Applied Psychology, 91, (1), 109-125. http://dx.doi.org/10.1037/0021-9010.91.1.109

38. Stahl, G.K., Makela, K., Zanderd, L., \& Maznevski, M.L. (2010). A look at the bright side of multicultural team diversity. Scandinavian Journal of Management, 26, 439-447. http://dx.doi.org/10.1016/j.scaman.2010.09.009

39. Stahl, G.K., Maznevski, M., Voigt, A., \& Jonsen, K. (2010a). Unravelling the effects of cultural diversity in teams: A metaanalysis of research on multicultural work groups. Journal of International Business Studies, 41, (4), 690-709. http://dx.doi.org/10.1057/jibs.2009.85

40. Stevens, F.G., Plaut, V.C., \& Sanchez-Burks, J. (2008). Unlocking the benefits of diversity. All-inclusive multiculturalism and positive organizational change. The Journal of Applied Behavioral
Science, $\quad 44, \quad$ (1),

http://dx.doi.org/10.1177/0021886308314460

$116-133$

41. Storey, J.P.S., Barbuto, J.E, Luthans, F., \& Bovaird, J.A. (2014). Meeting the challenges of effective international HRM: Analysis of the antecedents of global mindset. Human Resource Management, 53, (1), 131-155. http://dx.doi.org/10.1002/hrm.21568

42. Story, J. (2011). A development approach to global leadership. International Journal of Leadership Studies, 6, 375-389.

43. Takeuchi, R. (2010). A critical review of expatriate adjustment research through a multiple stakeholder view: progress, emerging trends, and prospects. Journal of Management, 36, 1040-1064. http://dx.doi.org/10.1177/0149206309349308

44. Van Oudenhoven, J.P., Mol, S., \& Van der Zee, K.I. (2003). Study of the adjustment of Western expatriates in Taiwan ROC with the Multicultural Personality Questionnaire. Asian Journal of Social Psychology, 6, (2), 159-170. http://dx.doi.org/10.1111/1467839X.t01-1-00018

45. Wang, D., Freeman, S., \& Zhu, C.J. (2013). Personality traits and cross-cultural competence of Chinese expatriate managers: A socio-analytic and institutional perspective. International Journal of Human Resource Management, 24, (20), 3812-3830. http://dx.doi.org/10.1080/09585192.2013.778314

46. Youssef, C.M., \& Luthans, F. (2012). Positive global leadership. Journal of World Business, 47, 539-547. http://dx.doi.org/10.1016/j.jwb.2012.01.007

47. Zajenkowska, A.M., \& Zimmerman, J.M. (2014). Relative culture: A study on contexting and extraversion among American and Polish expatriates. Baltic Journal of Management, 9, (1), 2-21. http://dx.doi.org/10.1108/BJM-05-2013-0087

S. Przytuła, M. Rozkwitalska, M. Chmielecki, Ł. Sułkowski, B. A. Basinska

Emigrantų ir vietinių vadybininkų tarpkultūrinès sąveikos pozityvaus organizacinio elgesio aspektu

Santrauka

Pagrindinis šio straipsnio tikslas - nustatyti individualų pozityvų nuokrypi, pasireiškiantị bendraujant emigrantams ir vietiniams vadybininkams. Tokie aiškiai išreikšti asmenybės bruožai kaip optimizmas, motyvacija pasiekimams, atviras mąstymas, asmeninis efektyvumas ir pažintinis smalsumas jų santykiams suteikia pozityvų poveikị: abipusę pagarbą, užuojautą, pasitenkinimą, laimèjimo, tobulèjimo, meistriškumo ir gerovès jausmą.

Straipsnyje išplečiama pozityvaus organizacinio elgesio perspektyva emigrantų požiūriu. Pradinèje projekto fazèje tyrimas buvo pradètas emigrantų ir vietinių vadybininkų populiacijoje ir sieké nustatyti pozityvias tarpkultūrines sąveikas individualiame, grupès ir organizaciniame lygmenyje multinacionalinių korporacijų užsienio dukterinėse kompanijose veikiančiose multikultūrinèse komandose.

Straipsnyje keliami šie tyrimo klausimai:

1. Kokie pozityvūs bruožai būdingi Lenkijos dukterinèse kompanijose dirbantiems emigrantams?

2. Kokie pozityvūs bruožai, emigrantų nuomone, būdingi lenkų vadybininkams?

3. Koks teigiamas tarpkultūrinès sąveikos poveikis pasireiškia individualiame lygmenyje?

Straipsnio pradžioje atliekama trumpa mokslinès literatūros apžvalga, siekiant išryškinti ryšius tarp pozityviosios organizacijos psichologijos (angl. Positive Organizational Psychology), pozityvaus organizacinio elgesio (angl. Positive Organizational Behaviour) ir pozityvios organizacijos studijų (angl. Positive Organizational Scholarship). Tada apibūdinami ryšiai tarp emigrantų ir vietinių vadybininkų. Taip pat išryškinama tam tikrų asmenybès savybių, lemiančių sèkmę atliekant užduotis užsienio organizacijoje, prasmè ir svarba. Išvadose pateikiamos analizės implikacijos ir apribojimai, taip pat tolimesnių tyrimų kryptys:

1 uždavinys: Kokie pozityvūs bruožai būdingi Lenkijos dukterinèse kompanijose dirbantiems emigrantams?

Iš lenkų vadybininkų perspektyvos buvo identifikuoti šie individualūs emigrantų vadybininkų pozityvūs bruožai: atvirumas kitiems žmonėms, pažintinis smalsumas, komunikabilumas ir noras dalintis 
S. Przytuła, M. Rozkwitalska, M. Chmielecki, L. Sułkowski,

Social Sciences /

Socialiniai mokslai. 2014. Nr. 4 (86)
B.A. Basinska. Cross-Cultural Interactions between Expatriates and Local Managers in the Light of Positive Organizational Behaviour

žiniomis. Be to, vietiniai vadybininkai vertina emigrantų žinias ir tarptautinę patirtị.

2 uždavinys: Kokie pozityvūs bruožai, emigranty nuomone, būdingi lenku vadybininkams?

Vadybininkai emigrantai teigè, kad lenkų vadybininkai yra darbštūs, atsidavę ir trokštantys nuolatinio mokymosi. Tarpasmeniniuose santykiuose lenkų vadybininkai yra atviri, šilti ir draugiški; daugelị klausimų jie priima emociškai. Vadybininkai iš užsienio išskyrè lankstumą, kūrybiškumą ir net gebejjimą improvizuoti.

3 uždavinys: Koks teigiamas tarpkultūrinès sąveikos poveikis pasireiškia individualiame lygmenyje?

Vadybinès patirties turtinimas, pažintinių gebèjimų tobulinimas, asmeninis tobulejimas, pasiekimo ir pasitenkinimo jausmas respondentu buvo išryškinti kaip teigiami tarpkultūrinio bendradarbiavimo rezultatai ir privalumai.

Reikšminiai žodžiai: tarpkultūrinè sąveika, pozityvus organizacinis elgesys, emigrantai.

First received: October, 2014

Accepted for publication: December, 2014 